\title{
Using ZooMS to identify fragmentary bone from the Late Middle/Early Upper Palaeolithic sequence of Les Cottés, France
}

\author{
Frido Welker ${ }^{\text {a, b, * }}$, Marie Soressi ${ }^{\text {c, a }}$, William Rendu ${ }^{\mathrm{d}}$, Jean-Jacques Hublin ${ }^{\mathrm{a}}$, \\ Matthew Collins ${ }^{b}$ \\ a Department of Human Evolution, Max-Planck Institute for Evolutionary Anthropology, Leipzig, Germany \\ b BioArCh, Department of Archaeology, University of York, York, United Kingdom \\ ${ }^{\mathrm{c}}$ Human Origins, Faculty of Archaeology, Leiden University, Leiden, The Netherlands \\ ${ }^{\mathrm{d}}$ Center for International Research in the Humanities and Social Sciences, UMI 3199, CNRS, New York University, New York, USA
}

\section{A R T I C L E I N F O}

\section{Article history:}

Received 10 October 2014

Received in revised form

11 December 2014

Accepted 14 December 2014

Available online 23 December 2014

\section{Keywords:}

Collagen

Châtelperronian

Les Cottés

Palaeolithic

ZooMS

Taxonomic richness

\begin{abstract}
A B S T R A C T
We report the application of a molecular barcode method (ZooMS) to identify fragmentary bone remains $(>2.5 \mathrm{~cm}$ ) from a Middle to Upper Palaeolithic sequence at Les Cottés, France. ZooMS uses peptide mass fingerprinting of collagen (the most abundant protein in bone) to discriminate fauna (typically to genus level). Using previously reported peptide markers we initially conducted a blind test using 34 morphologically identified bones, followed by the application of ZooMS on 145 morphologically unidentified bone specimens. For the blind test, ZooMS was in agreement with morphological identifications in all cases, but in some instances taxonomic resolution is lower than morphological identifications. Further, 93.8\% (136/145) of spectra obtained for morphologically unidentified bone specimens result in identifications that cannot be taxonomically improved by ZooMS. These include ten bone specimens showing signs of carnivore digestion. Focussing on the unidentified bone specimens of the Châtelperronian unit at Les Cottés (US06), ZooMS identified an additional $\approx 30 \%$ of the total number of bones discovered, increasing the total number of identified bone specimens to $61.8 \%$. Further, ZooMS revealed higher taxonomic richness compared to morphological identifications for US06, thereby providing a more informed interpretation of the faunal community present at Les Cottés during the Châtelperronian.
\end{abstract}

(๑) 2014 Elsevier Ltd. All rights reserved.

\section{Introduction}

Palaeolithic sites often contain large numbers of bone specimens that are taxonomically unidentified due to high fragmentation on faunal and human bone specimens as the result of carnivore activity (for example Costamagno et al., 2008), anthropogenic fragmentation (examples include Costamagno et al., 2006; Gaudsinski and Roebroeks, 2000; Niven, 2007; Mussini et al., 2012) or because of taphonomic processes (Behrensmeyer, 1978; Lam and Pearson, 2005; Nielsen-Marsh et al., 2007; Todd and Rapson, 1988). Anatomically incomplete bone specimens often lack morphologically discriminatory characteristics, impeding taxonomic identification. Such taxonomically unidentified bone

\footnotetext{
* Corresponding author. Department of Human Evolution, Max-Planck Institute for Evolutionary Anthropology, Deutscher Platz 6, D-04103 Leipzig, Germany. Tel.: +49(0)3413550749.

E-mail address: frido_welker@eva.mpg.de (F. Welker).
}

specimens potentially contain important behavioural (d'Errico et al., 2003; Rendu, 2010; Romandini et al., 2014; Soressi et al., 2013), ecological (Discamps et al., 2011) or molecular (Richards et al., 2008; Castellano et al., 2014) information.

The Châtelperronian is found in stratigraphy between the late Mousterian and Aurignacian technocomplexes but chronologically overlaps with the earliest phases of the latter (Hublin et al., 2012). It is associated with the replacement of Neanderthals by anatomically modern humans in Western Europe (Soressi and Roussel, 2014; Hublin, in press). Recent insights into ungulate biozones in southwest France for MIS 5-3 (Discamps et al., 2011; Discamps, 2013) and attempts to model adaptive responses of hunter-gatherers to the onset of Heinrich Stadial 4 (Banks et al., 2013) have started to provide a chronological and ecological framework to understand faunal assemblages at a more temporally restricted level. Despite this, the number of Châtelperronian faunal assemblages that could be included in such studies is very limited due to the fragmentary nature of most assemblages, the probability of mixing between 
Table 1

Morphologically identified NISP counts for US02-US08 at Les Cottés, modified to resemble exclusive taxonomic groups using ZooMS (field seasons 2006-2010).

\begin{tabular}{|c|c|c|c|c|c|}
\hline & \multicolumn{5}{|c|}{ Morphological identifications (NISP) } \\
\hline & US08 & U06 & US04inf & US04sup & USO2 \\
\hline Bovini & 36 & 20 & 24 & 9 & 3 \\
\hline Capra sp. & & & & $1^{\mathrm{A}}$ & \\
\hline Chamois & & & & & 1 \\
\hline Rangifer tarandus & 45 & 41 & 271 & 330 & 271 \\
\hline Cervus elaphus & 1 & & & & \\
\hline Capreolus capreolus & & & 1 & & \\
\hline Equidae & $16^{\mathrm{B}}$ & $11^{\mathrm{C}}$ & $96^{\mathrm{B}}$ & $30^{\mathrm{C}}$ & $4^{\mathrm{C}}$ \\
\hline Suidae & & & 1 & & \\
\hline Rhinocerotidae & 1 & & & & \\
\hline Elephantidae & & 3 & & 1 & \\
\hline Canidae $^{\mathrm{D}}$ & & & 1 & 1 & \\
\hline Hyaenidae $^{\mathrm{E}}$ & 2 & 6 & 5 & 3 & \\
\hline NISP total & 101 & 81 & 399 & 375 & 279 \\
\hline NTAXA & 6 & 5 & 7 & 7 & 4 \\
\hline
\end{tabular}

Morphological identifications concern: A) Capra ibex, B) includes Equus hydruntinus $(\mathrm{N}=1)$, all other specimens Equus caballus, C) Equus caballus/ferus for all specimens, D) Vulpinae for all specimens, and E) Crocuta sp. for all specimens.

Châtelperronian and late Mousterian or Aurignacian units for some sites (as pointed out by Discamps, 2013), and the overrepresentation of larger, identifiable bone fragments in collections from older excavations (Boyle, 2007; Discamps et al., 2011; Grayson and Delpech, 2002, 2008; Mellars, 2004; Soulier and Mallye, 2012). As a result, average ungulate biomass and biozone(s) associated with the Châtelperronian remain to be formally defined (Discamps, 2013).

In addition, identification of hominin bones for the Middle to Upper Palaeolithic transition are important because only a small number of specimens are currently available for late Neanderthals, and almost none for early modern humans in Western Europe (Churchill and Smith, 2000; Hoffecker, 2009; Hublin, in press.). Molecular identification methods have the potential to identify additional hominin remains among fragmentary bone assemblages, allowing additional genomic and proteomic study of these complex technocomplexes. Peptide markers for humans have been published previously (Buckley and Kansa, 2011).

Here, we explore the potential of proteomically identifying morphologically unidentifiable bone fragments encountered at Palaeolithic sites by employing ZooMS (Buckley et al., 2009) at Les Cottés, a stratified well-dated transitional site containing Mousterian (US08), Châtelperronian (US06), Protoaurignacian (US04inf) and Early Aurignacian archaeological units (US04sup and US02; Jacobs et al., 2015; Roussel and Soressi, 2013; Soressi et al., 2010; Talamo et al., 2012). ZooMS is a quick and simple massspectrometric method to identify mammalian bone fragments up to family/genus level by observing mass values for 7 selected collagen peptides (peptide markers A-G). We test our ZooMS approach on 34 samples with known morphological identifications (the blind test sample). Then, we perform the same analysis on 145 bone specimens without a morphological identification, including ten bone specimens showing signs of carnivore digestion. ZooMS results are compared with morphological identifications for the same archaeological units (NISP $=1235$ ) in terms of taxonomic richness (NTAXA).

\section{Material and methods}

\subsection{Les Cottés}

Les Cottés, France, is a cave site spanning the Middle to Upper Palaeolithic transition on the south-western margin of the Paris Basin (Talamo et al., 2012). It is located at the northern edge of the known distribution of both the Châtelperronian and the Protoaurignacian (Soressi and Roussel, 2014). The well-documented stratigraphy consists of archaeologically sterile units (US-01, US03, US-05 and US-07) between archaeological units (US-02, US04sup, US-04inf, US-06 and US-08) and has attracted several fieldwork campaigns since discovery of the site in 1878 (Bastin et al., 1976; Lévêque, 1997; Pradel, 1967; Soressi et al., 2010). Current excavations focus on deposits in front of the cave entrance (Soressi et al., 2010).

Preliminary faunal analysis indicates that bovid and horse dominate the Mousterian unit (51\%, US08, see Table 1). Reindeer is dominant in subsequent layers (up to $97 \%$ in US02; Frouin et al., 2013). The shift to a reindeer-dominated assemblage has been related to increasingly cooler environmental conditions and a change in the site occupation pattern for the Early Aurignacian unit (Frouin et al., 2013). The Châtelperronian unit has the lowest NISP of the five morphologically identified assemblages, with a small number of taxa ( $n=$ five) present (Table 1). Carnivore and anthropogenic modifications are roughly equal in the Mousterian unit US08 (15.5\% and 17.0\% respectively) while modifications in the Châtelperronian and Proto/Early Aurignacian units are dominated by those of anthropogenic origin (US06, roughly $11 \%$ and $24 \%$, Proto/Early Aurignacian units $<2 \%$ and up to $30 \%$, respectively, percentages after Talamo et al., 2012).

\subsection{Sample selection}

All faunal data from Les Cottés were derived from recent excavations (field seasons 2006-2012). Individual bone specimens $>2.5 \mathrm{~cm}$, teeth, and articulated extremities were piece-plotted in three dimensions. The blind test included 34 bone specimens with known morphological identifications. In addition, the majority of these bones have been directly radiocarbon dated (Talamo et al., 2012). The morphologically unidentified sample comprised 145 bones from various levels at the site (Table 2) but focussing on the Châtelperronian unit (US06). These include ten bones showing signs of carnivore digestion. Only piece-plotted bones $>2.5 \mathrm{~cm}$ were selected.

Table 2

Sample selection by archaeological unit. Numbers in parentheses indicate digested bone specimens. Bone counts for field seasons $2006-2012$.

\begin{tabular}{|c|c|c|c|c|c|}
\hline Unit & Archaeological attribution & Blind test sample & ZooMS identified sample & Morphologically identified sample & $\begin{array}{l}\text { Total number of faunal } \\
\text { remains }>2.5 \mathrm{~cm}\end{array}$ \\
\hline US-02 & Early Aurignacian & 6 & $18(1)$ & 279 & 877 \\
\hline US-04sup & Early Aurignacian & 7 & $15(1)$ & 375 & 1247 \\
\hline US-04inf & Protoaurignacian & 6 & $18(2)$ & 399 & 1460 \\
\hline US-06 & Châtelperronian & 6 & $78(2)$ & 81 & 259 \\
\hline US-08 & Mousterian & 9 & $16(4)$ & 101 & 409 \\
\hline Total & & 34 & 145 & 1235 & 4202 \\
\hline
\end{tabular}




\subsection{ZooMS methodology}

Bone specimens $(n=179)$ were sampled using pliers $(\approx 10-30 \mathrm{mg}$ ) and demineralised for one day to one week in $250 \mu \mathrm{l}$ $0.6 \mathrm{M} \mathrm{HCL}$ at $4{ }^{\circ} \mathrm{C}$. Following demineralisation, samples were centrifuged for $1 \mathrm{~min}$ at $13 \mathrm{k} \mathrm{rpm}$, after which the supernatant (consisting of HCL and the soluble collagen fraction) was removed. Samples were then rinsed three times in $250 \mu$ l ultrafiltered water and finally, $100 \mu \mathrm{l} 50 \mathrm{mM}$ Ambic (ammonium bicarbonate buffer, $\mathrm{pH}$ 8.0) was added to each sample. Samples were incubated at $65^{\circ} \mathrm{C}$ for $1 \mathrm{~h}$ to gelatinise the demineralised insoluble collagen fraction. Samples were centrifuged at 13,000 rpm for $1 \mathrm{~min}$ after which $50 \mu \mathrm{l}$ of the supernatant (containing the gelatinized collagen) was transferred to a new eppendorf tube to which $1 \mu$ l trypsin (Promega) solution was added. Trypsin digestion was carried out overnight for $17.5 \mathrm{~h}$ at $37^{\circ} \mathrm{C}$. Afterwards, samples were centrifuged for $1 \mathrm{~min}$ at $13 \mathrm{k} \mathrm{rpm}$, following which $1 \mu \mathrm{l}$ of $5 \%$ TFA was added to stop enzymatic digestion. A $\mathrm{C}_{18}$ ZipTip (Agilent) was used for peptide extraction, which were eluted using $50 \mu \mathrm{l}$ of $50 \% \mathrm{ACN}$ in $0.5 \%$ TFA.

MALDI-TOF-MS analysis followed previously established protocols (Buckley et al., 2009) but used $1 \mu \mathrm{l}$ sample solution and $1 \mu \mathrm{l}$ matrix solution. MALDI-TOF-MS replicates $(n=3$; mass range 900-4000) were averaged for each sample and manually inspected for the presence of relevant peptide markers (A-G) in mMass $v$. 5.5.0 (Strohalm et al., 2010). Naming of peptide markers follows Kirby et al. (2013). Peptide markers P1 and P2 are recent additions to the original scheme, and selected to separate Cetacea and Pinnipeds (Buckley et al., 2014). They are not taken into account here as their values remain unreported for several species present.

\subsection{ZooMS taxa identification}

Spectra were compared with peptide marker series (A-G) for all available vertebrate species (Buckley et al., 2009, 2014; Kirby et al., 2013). Marker series are similar for some closely related species. For instance, differentiating Equus caballus and Equus hydruntinus using ZooMS is for now not possible. As a result, morphological identifications for these taxa are here grouped together to make morphologically identified assemblages comparable to assemblages identified by ZooMS. All such taxonomic groups are mutually exclusive. Full morphological identifications are provided in Table 1.

Further, ZooMS spectra assigned to these groups contain either a single peptide marker unique to such a group (for example 1208.6 for peptide marker A, identifying Bovini), or a combination of peptide markers defining a group (for example 1453.7 for marker B and 2145.1 for peptide marker D, identifying Rhinocerotidae). Spectra not meeting these criteria will be provided with possible taxonomic assignments, but are excluded from further richness analysis.

\subsection{Richness analysis}

The number of taxa (NTAXA) identified for a given assemblage is often correlated with the total number of identified specimens (NISP). We performed rarefaction analysis (Lyman and Ames, 2007; Magurran, 2004) to investigate NTAXA differences between faunal assemblages as it allows the inclusion of samples with very different assemblage sizes. Rarefaction curves predict an average expected number of taxa by sample size, as well as $95 \%$ confidence intervals, here calculated using PAST v. 3.0 (Hammer et al., 2001). Rarefaction analysis assumes nestedness of included faunal assemblages; that is, each included assemblage is derived from the same possible combination of species (Gotelli and Colwell, 2011; Kintigh, 1984). The degree of nestedness ( $\mathrm{T}$ ) indicates how nested multiple faunal assemblages are (Ulrich, 2006), in other words, how likely they were derived from the same biological community. Nestedness values range from "cold" $\left(0^{\circ} \mathrm{C}\right.$, fully nested, an ordered sub-sample indicating a similar parent faunal composition) to "hot" $\left(100{ }^{\circ} \mathrm{C}\right.$, not nested, a random pattern of species without shared species between the compared faunal assemblages), and are measured using Nestedness (Ulrich, 2006), a statistical test to test such relationship between different biological communities. Nestedness was assessed for several combinations of faunal assemblages (ZooMS and morphology assemblages for each archaeological unit separately and for all assemblages together $(N=10, \mathrm{NISP}=1371))$. Chi-square comparisons, commonly used to compare observed frequencies between two ordinal variables, were not used as small sample size and a high number of expected low frequencies (below five) hamper the underlying criteria.

\section{Results}

\subsection{Blind test results}

Of the 34 bone specimens with morphological identifications (Table 3), one could not be identified using peptide markers. Of the remaining 33 specimens, ZooMS provides an identification as specific as the morphological identification (14 instances) or more specific (14 instances). For five bone specimens, a ZooMS identification could be made that includes the morphological identification but does not exclude other possibilities (sample specific details can be found in Supplementary Table 1). This is often due to the absence of a specific peptide marker in the relevant spectrum. For example, two bone specimens were identified morphologically as reindeer while a ZooMS identification of Reindeer/Capra sp. must be given based on a peptide mass of 3093.4 for marker $G$ but the absence of marker A.

\subsection{ZooMS sample results}

A summary of taxonomic identifications by ZooMS for morphologically undiagnostic bone specimens is found in Table 4 (sample specific details can be found in Supplementary Table 2 and example spectra in Fig. S1). One sample remained indeterminate due to poor spectra quality (Fig. S1d) and, excluding more general identification categories like Bovidae or Reindeer/Capra $(N=9)$, an overall success rate of $93.8 \%$ was achieved $(99.3 \%$ including broader identifications but excluding the one indeterminate).

For the Châtelperronian unit US06, the ZooMS results increased the taxonomic identifications of bone specimens from this level

Table 3

Blind test results for 34 samples with known morphological identifications. + more specific ZooMS identifications, = equally specific ZooMS identifications, and - indicates broader ZooMS identifications.

\begin{tabular}{|c|c|c|c|c|}
\hline Morphological identification & $\mathrm{N}$ & ZooMS identification & $\mathrm{N}$ & $+1-$ \\
\hline \multirow[t]{4}{*}{ Reindeer } & 14 & Reindeer & 10 & $=$ \\
\hline & & Reindeer/Capra & 2 & - \\
\hline & & Bovidae/Cervidae & 1 & - \\
\hline & & Indeterminate & 1 & - \\
\hline \multirow[t]{2}{*}{ Bovini } & 4 & Bison sp./Bos sp. & 3 & $=$ \\
\hline & & Bovidae/Cervidae/Equidae & 1 & - \\
\hline Equidae & 1 & Equidae & 1 & $=$ \\
\hline \multirow[t]{2}{*}{ Bison/Horse } & 4 & Bison sp./Bos sp. & 3 & + \\
\hline & & Bovidae/Cervidae/Equidae & 1 & - \\
\hline \multirow[t]{2}{*}{ Bison/Rhinocerotidae } & 2 & Bison sp./Bos sp. & 1 & + \\
\hline & & Rhinocerotidae & 1 & + \\
\hline \multirow[t]{3}{*}{ Ungulate } & 9 & Reindeer & 7 & + \\
\hline & & Bison sp./Bos sp. & 1 & + \\
\hline & & Equidae & 1 & + \\
\hline
\end{tabular}


Table 4

ZooMS identifications for 145 morphologically undiagnostic bone specimens. Numbers in parentheses indicate digested bone specimens.

\begin{tabular}{|c|c|c|c|c|c|c|}
\hline & \multirow[t]{2}{*}{ Possible genera/species } & \multicolumn{5}{|c|}{ ZooMS identification } \\
\hline & & US08 & U06 & US04inf & US04sup & US02 \\
\hline Bovidae & & & 1 & & & \\
\hline Bovidae/Cervidae & & & 1 & & & \\
\hline Bovini & Bison sp./Bos sp. & $10(1)$ & 23 & 2 & & \\
\hline Capra sp. & Capra ibex & & 1 & & & \\
\hline Reindeer/Capra & Rangifer tarandus/Capra sp. & & 4 & & & 1 \\
\hline Reindeer & Rangifer tarandus & $4(3)$ & $23(1)$ & $4(1)$ & $6(1)$ & $12(1)$ \\
\hline Cervid/Saiga & Cervus sp./Alces alces/Megaloceros sp./Saiga tatarica/Dama sp. & & 4 & & & \\
\hline Equidae & Equus sp. & 2 & $13(1)$ & $11(1)$ & 8 & 1 \\
\hline Suidae & Sus scrofa & & 1 & & & \\
\hline Rhinocerotidae & Coelodonta antiquitatis & & 3 & & & 4 \\
\hline Elephantidae & Mammuthus primigenius & & 2 & 1 & & \\
\hline Canidae & Canis sp./Vulpes lagopus & & 1 & & & \\
\hline Carnivora & & & 1 & & & \\
\hline Indeterminate & & & & & 1 & \\
\hline NISP total & & 16 & 78 & 18 & 15 & 18 \\
\hline
\end{tabular}

from 31.7 to $61.8 \%$ (160/259), with a species composition relatively similar to the morphological identifications for the same level (Table 1).

A number of taxa are present in the ZooMS sample set that were not included in the blind test. The Suidae identification (sample 9964) is supported by all peptide markers presented by Buckley et al. (2009) for pig (1180.6, 1453.7, 1550.8, 2131.1, 2820.3, 2883.5 and 3033.4). Three samples were identified as Elephantidae (samples 9919, 10,000 and 9973). These identifications are supported by Proboscidea specific markers at 1518.8, 2018.0 and 2277.2, and an Elephantidae specific marker at 3015.5 (following Buckley et al., 2009; Buckley et al. 2011). Seven samples were identified as Rhinocerotidae on the basis of 1453.7 together with 2145.1 (peptide markers B and D, respectively). A single sample was identified as a canid on the basis of 1226.6 for marker A, with the other peptide markers in agreement with a carnivore attribution. Finally, one bone specimen was identified as Capra sp. on the basis of diagnostic

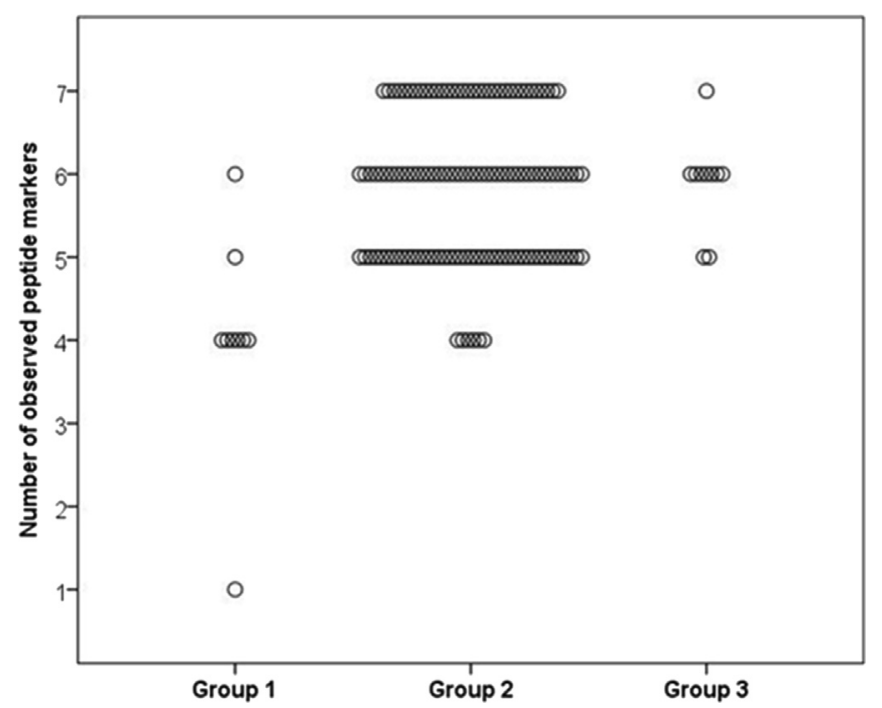

Fig. 1. Number of observed peptide markers by taxonomic identification. Group 2 includes taxonomic identifications exclusive to other groups $(N=126)$. Group 1 includes identifications that are not exclusive to other groups (eg. "Bovidae", $N=9$ )). Group 3 includes digested bone specimens $(N=10)$. Average number of observed peptide markers is $5.81 \pm 0.86,3.90 \pm 1.17$ and $5.90 \pm 0.58$, respectively. Group 1 and 2 differ significantly ( $\mathrm{t}=-6.347, \mathrm{p}=0.000)$ while group 2 and 3 do not $(t=0.464$, $p=0.651)$. peptide marker G (3093.4; Buckley et al., 2010; Campana et al., 2013) in combination with 1180.2 for marker A.

The level of identification for digested bone specimens, and the number of peptide markers present for such specimens, did not statistically differ between undigested and digested bone specimens (see Fig. 1 and Fig. S1A + B).

\subsection{Richness analysis}

Nestedness values for ZooMS and morphologically identified faunal assemblages from the same archaeological unit are $0.00{ }^{\circ} \mathrm{C}$ (US04sup and US08), $3.92{ }^{\circ} \mathrm{C}$ (US04inf), $5.13^{\circ} \mathrm{C}$ (US06) and $9.56{ }^{\circ} \mathrm{C}$ (US02), indicating that ZooMS and morphological identifications differ minimally for the respective units. All five ZooMS faunal assemblages and five morphologically identified faunal assemblages together have a nested value of $12.91{ }^{\circ} \mathrm{C}$, indicating a relatively comparable faunal composition among all assemblages (Fig. 2). The overall comparisons might be driven by smaller sample sizes for four out of five ZooMS faunal assemblages, as their NTAXA are correlated with sample size $(r(2)=0.969, p=0.002$; Fig. $3 \mathrm{~A})$. However, this is not the case for the morphologically identified

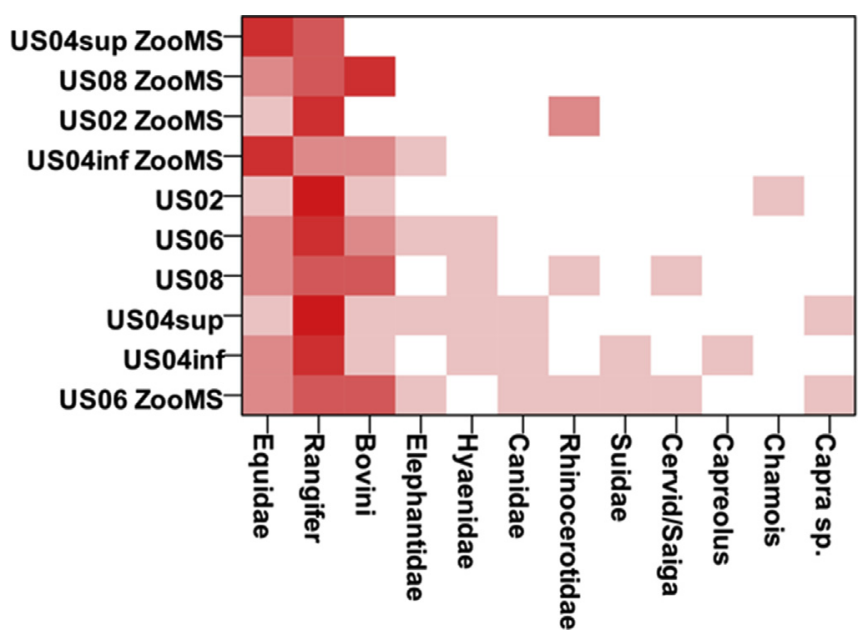

Fig. 2. Nestedness of taxa for morphological and ZooMS fauna assemblages for Les Cottés. Colours correspond to \% NISP abundance by unit $(0-10 \%, 10-25 \%, 25-50 \%$, $50-75 \%$ and $75-100 \%$ ). Overall nestedness value is $12.91{ }^{\circ} \mathrm{C}$ (see text for individual nestedness values). 

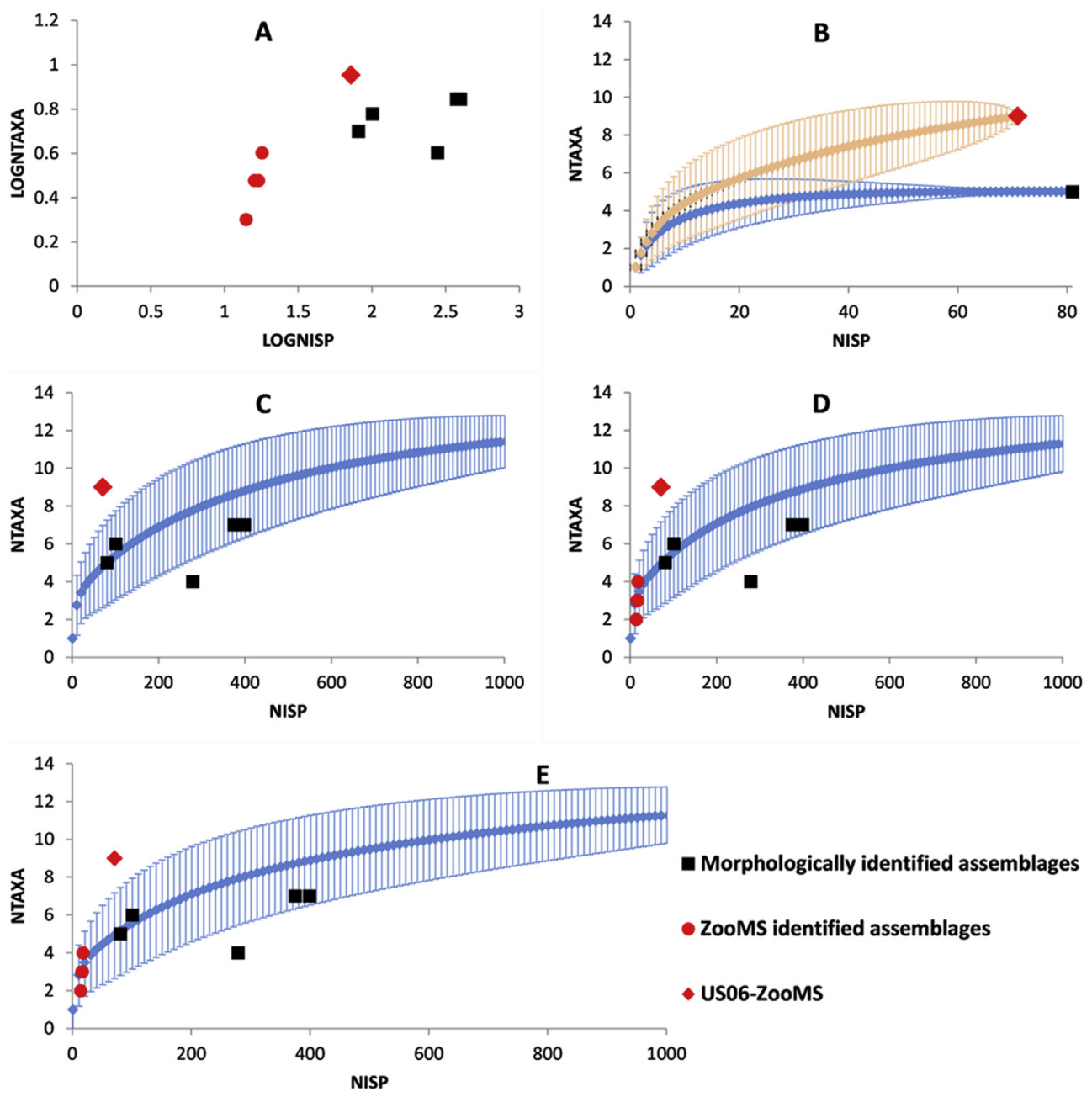

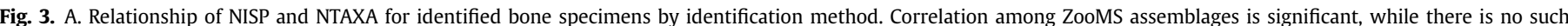

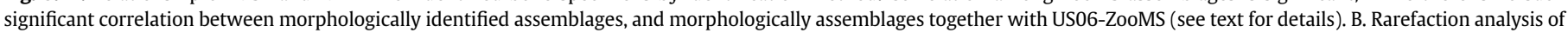

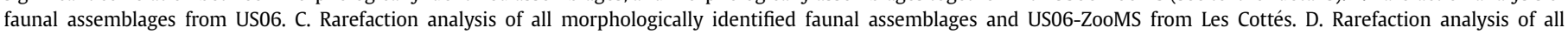

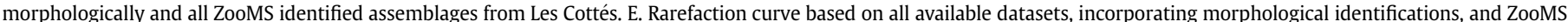

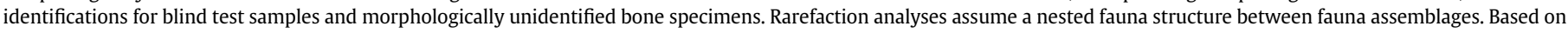
NISP and NTAXA data from Table 1 and Table 4. Rarefaction curves and standard deviations calculated using PAST v. 3.0 (Hammer et al., 2001 ).

faunal assemblages (either with or without US06-ZooMS, respectively $r(4)=-0.153, p=0.386$ or $r(3)=0.279, p=0.3325$ ).

Rarefaction analysis indicates NTAXA for US06-ZooMS is unexpectedly high at a 2-sigma standard deviation level (Fig. 3B-E). NTAXA values for the other ZooMS faunal assemblages fall within the expected distribution (Fig. 3D). Similarly, NTAXA for the morphological faunal assemblages fall within the expected variation for four out of five assemblages, both without (Fig. 3C) and with (Fig. 3D) the four smaller ZooMS faunal assemblages. Neither does the analysis change when including blind test specimens with an improved taxonomic identification after ZooMS $(N=14$, Fig. 3E).The one morphologically identified faunal assemblage that falls outside the expected distribution is USO2, which is dominated by reindeer (97\%) and contains just three other taxa (Table 1 ).

\section{Discussion}

\subsection{Taxa identification}

The blind test indicates that ZooMS identifications are in agreement with morphological identifications. Although proteomic

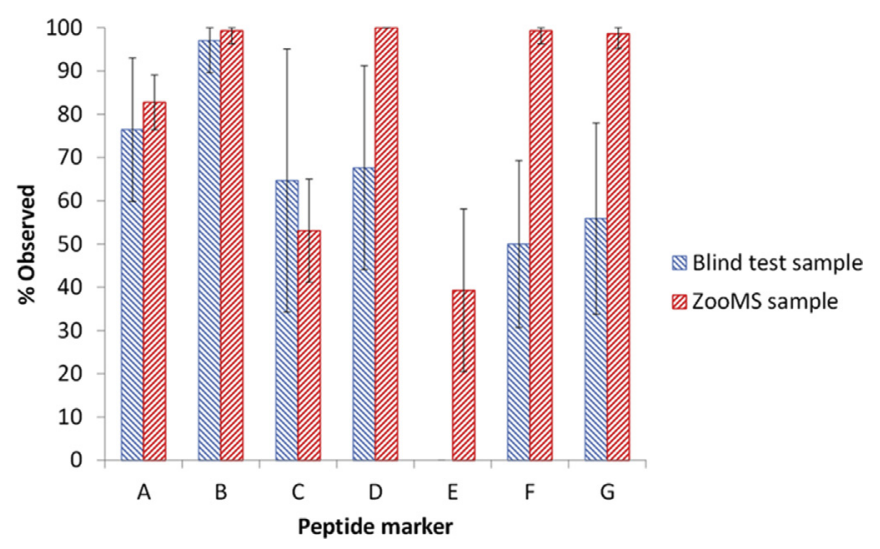

Fig. 4. Percentage of observations of peptide markers A-G for the blind test samples and ZooMS samples. Peptide markers B, D, F and G occur more frequent compared to markers A, C and E. Error bars indicate 1-sigma standard deviation based on average peptide marker observance by archaeological unit. 
identifications in a number of instances $(n=5)$ include taxonomic groups excluded by morphological identifications, in no instance were conflicting identifications obtained. This is important when comparing faunal assemblages identified by ZooMS with those identified morphologically. Together with the morphologically unidentified samples $(\mathrm{n}=145)$, an overall success rate for ZooMS samples of $91.6 \%$ was obtained. The ZooMS blind test results are excluded from further comparisons as this faunal assemblage included samples also used in the morphologically identified assemblages. For general reference, a NISP count by archaeological unit including all studied bone specimens (either identified by morphology, unidentified by morphology but identified by ZooMS, and blind test samples with improved identifications by ZooMS) is provided in Supplementary Table 3.

MALDI-TOF-MS taxonomic identification is currently based on 7 selected peptide markers ( 9 with the recent addition of P1 and P2; Buckley et al., 2014). The absence of a specific peptide marker in any given spectra has implications for the taxonomic level at which an identification will be made. For example, spectra identified as "Bovidae" $(n=1)$, "Bovidae/Cervidae" $(n=1)$ or "Reindeer/Capra sp. " $(n=5)$ are due to the absence of a single marker (peptide marker A, C and A, respectively, see Fig. S1C for an example). Comparing the occurrence of specific markers reveals that markers $\mathrm{A}, \mathrm{C}$ and $\mathrm{E}$ occur at lower frequencies compared to markers B, D, F and G (Fig. 4). This implies that an observation of peptide marker $A$ and/or $C$ is of more importance in a final identification of a spectrum compared to the observance of peptide marker $E$. The number of peptide markers observed is significantly different between exclusive taxonomic identifications compared to non-exclusive taxonomic identifications (see Fig. 1 for statistics). An implication of these observations is that species with different mass values for marker B, D, F and $G$ are more easily discriminated among fragmentary bone specimens, or separated from closely related species. This would include the identification of hominins, which contain unique mass values for three peptide markers $(1219.6+1235.6,1477.8$ and 2832.4 for peptide markers A, B and E, respectively; Buckley and Kansa, 2011). The proteomic identification of such fragmentary bone specimens as hominins in key archaeological contexts would facilitate subsequent proteomic and genomic analysis, thereby providing a much needed detailed temporal and geographic understanding of the Middle to Upper Palaeolithic transition, an issue raised previously as well (Churchill and Smith, 2000; Hoffecker, 2009; Hublin, in press). A similar argument pertains to identifying faunal taxa whose fragmentation (history) effectively removes morphological diagnostic criteria for identification.

The use of selected peptide markers further implies that full distinction between (very) closely related species cannot be made. Of importance are the marker similarities between Bos sp. and Bison sp. (identified as Bos sp./Bison sp.), different species in the genus Equus (identified as Equidae), differentiation in the genus Capra (identified as Capra sp.; Buckley et al., 2010; Campana et al., 2013) and separation between Elephantidae (Buckley et al., 2011). Identifications as "Cervid/Saiga" cannot be improved proteomically, despite marker A being absent in three out of four of such identifications (marker A would be $1180.6+1196.6$ for both Saiga tatarica and relevant Cervid species). Because "Cervid/Saiga" excludes roe deer and reindeer as taxonomic possibilities based on peptide marker G (3093.4 for reindeer, 3059.4 for roe deer and 3033.4 for Cervid/Saiga), these identifications have been retained as they are exclusive to any of the other recognised taxonomic groups. Based on morphology and species distributions during MIS3 (Boyle, 2007), an attribution to a cervid seems more probable.

\subsection{Taxa richness}

It is well-known that the number of observed taxa is often dependent on sample size (Grayson, 1984; Lyman, 2008; Magurran, 2004). Despite their small size, the ZooMS faunal assemblages for US02, US04sup, US04inf and US08 are composed of taxa that are identified morphologically for these units (compare Table 1 with Table 4). Additionally, two of these ZooMS faunal assemblages incorporate one additional taxon for US04inf (Elephantidae, $N=1$ ) and US02 (Rhinocerotidae, $N=4$ ) that were not identified morphologically. The small size of the samples explains the absence of several other infrequently present taxa in respective units.

For the digested bone specimens, three taxa were identified (Equidae, Rangifer and Bos/Bison). The full identification for all studied digested specimens $(n=10)$ and the absence of a statistical difference in the number of peptide markers observed for these bone specimens compared to non-digested bone specimens mean that ZooMS has the potential to further characterise carnivoreherbivore interactions and the deposition of prey species by carnivores and/or hominins for mixed bone assemblages (such as the case for US08 and US06; Soressi et al., 2010).

The ZooMS faunal assemblage of US06 is similar in size to the morphologically identified faunal assemblage (71 and 81, respectively). Despite their similarity in sample size, NTAXA in the morphologically unidentified ZooMS assemblage is almost double (nine and five) that of the morphologically identified assemblage, a difference which is statistically significant (Fig. 3B). Whether this a common feature of morphologically unidentified subsets of bone assemblages requires further investigation. The additional taxa are present for carnivores (Canidae), medium-sized mammals (Capra sp., Suidae, Cervid/Saiga) and large-sized mammals (Rhinocerotidae). Wider comparison, however, reveals that none of the taxa identified for US06 by ZooMS is absent from the morphologically identified bone specimens from other units at Les Cottés. As a result, US06-ZooMS has a higher NTAXA compared to any of the other archaeological units (Fig. 3A). Further, the slope of the rarefaction curve for the US06-ZooMS faunal assemblage in Fig. 3B indicates that the assemblage has not been sampled to redundancy. This suggests that additional sampling may add other (rare) taxa to the overall faunal composition.

Within this NTAXA richness for US06-ZooMS, groups such as Equidae (containing E. caballus and E. hydruntinus), Bison sp./Bos sp., Cervid/Saiga sp. and Canidae have the potential to contain multiple species that in individual cases may potentially be identified more precisely based on morphological characteristics. The samples studied here lacked such morphological characteristics, except for Cervid/Saiga sp. for which an attribution to a cervid species is more likely (see above). For US06, the NTAXA derived from morphological identifications is not decreased artificially as there is no presence of Cervus sp., Megalocerus sp., Dama sp., Alces sp, Saiga tatarica, or E. hydruntinus, although for the latter two specimens have been identified at the site (US08 and US04inf, see Table 1). Therefore, it is possible that ZooMS underestimates NTAXA richness, as defined from a proteomic peptide marker approach. A combined approach using ZooMS and morphology will, therefore, provide additional details on taxonomic composition for closely related species.

The additional taxa identified by ZooMS - Capra sp. (probably Capra ibex), Cervid/Saiga (probably Cervus elaphus or Megaloceros giganteus), Suidae (Sus scrofa), Rhinocerotidae (Coelodonta antiquitatis) and Canidae (Canis sp./Vulpes sp.) - are consistently present at contemporaneous sites (Discamps et al., 2011). Comparison with Boyle (2010) reveals that such taxa form a minor component of Châtelperronian faunal assemblages (respectively 0.72\%, 8.65\%, 0.41\% and 2.88\%; carnivore percentages are not provided by Boyle, 2010). 
The addition of these taxa to the overall US06 faunal assemblage has several implications. Without these, the identified faunal composition might be related to a dry, steppe-like environment. The identification of boar could be taken as indicating the presence of patches of woodland (Boyle, 2000), thereby adding an additional ecological component. The identification of four bone specimens as Cervid (but excluding roe deer or reindeer based on peptide marker $\mathrm{G}$, see above) is especially unfortunate from an ecological point of view as C. elaphus or Megaloceros giganteus (the two most likely species candidates) have different ecological tolerances (Boyle, 2000; Chritz et al., 2009).

Recent analysis of clay minerals at Les Cottés revealed short local oscillations during the Middle to Upper Palaeolithic Transition towards more temperate and/or wetter conditions (Frouin et al., 2013), but noted that such oscillations were not recorded by the available faunal data at the time. The additional taxa identified here might correspond to such short-term environmental oscillations, and corresponds with the dominance of different ungulate species for several Châtelperronian units in southwest France, with an ungulate biomass index for US06 (0.52) comparable to those for Roc de Combe level 8 (0.52) and Quinçay level Em (0.56; Discamps et al., 2011; Discamps, 2013). As such, the study of fragmentary bone assemblages using ZooMS is contributing to wider debates about human-environment interactions during the Châtelperronian.

\section{Conclusion}

The blind test provides confirmation that ZooMS is a reliable way to taxonomically identify morphologically unidentifiable bone specimens. The taxonomic level to which such identifications can be made is strongly related to which peptide markers are present, especially concerning peptide markers $\mathrm{A}$ and $\mathrm{C}$, and the taxonomic position of the relevant species. ZooMS is currently unable to separate closely related species (such as Bos sp. and Bison sp.) based on available peptide marker series. The taxonomic identification of digested bone specimens holds promise for our understanding of carnivore as accumulators of (parts of) bone assemblages. ZooMS data are in agreement with morphological identifications made for the same archaeological units at Les Cottés and recognised faunal communities during MIS3 in southwest France. For the Châtelperronian unit US06, observed NTAXA in the ZooMS assemblage is unexpectedly high. This cannot be explained by sample size, the body size of the added taxa (as these range from medium to large-sized mammals), or the absence of the identified taxa during the Châtelperronian (as all have been identified at other, contemporaneous, Châtelperronian sites). Instead, ZooMS reveals faunal components that occur at low frequencies among the unidentifiable component of bone assemblages. The high success rate of ZooMS (91.6\%) implies that ZooMS in combination with morphological identifications is capable of providing a more complete taxonomic understanding of faunal ecology and taxa composition during key stages of human evolution.

\section{Acknowledgements}

Keri Rowsell and Adam Dowle are thanked for technical support. F.W. was financially supported during part of this research by a VSBfonds scholarship. We thank S. Wolverton and three anonymous reviewers for their comments, which greatly improved the paper. The ongoing excavation at Les Cottes is run with funding from the French Ministry of Culture and the Max Planck Institute for Evolutionary Anthropology.

\section{Appendix A. Supplementary data}

Supplementary data related to this article can be found at http:// dx.doi.org/10.1016/j.jas.2014.12.010.

\section{References}

Banks, W.E., d'Errico, F., Zilhao, J., 2013. Human-climate interaction during the Early Upper Paleolithic: testing the hypothesis of an adaptive shift between the Proto-Aurignacian and the Early Aurignacian. J. Hum. Evol. 64, 39-55.

Bastin, B., Lévêque, E., Pradel, L., 1976. Mise en evidence de spectres polliniques interstadiares entre le Moustérien et le Périgordien ancient de la grotte des Cottés (Vienne). C.R. Acad. Sci. 282, 1261-1264.

Behrensmeyer, A.K., 1978. Taphonomic and ecologic information from bone weathering. Paleobiology 4 (2), 150-162.

Boyle, K.V., 2000. Reconstructing Middle Palaeolithic subsistence strategies in the south of France. Int. J. Osteoarchaeol 10, 336-356.

Boyle, K.V., 2007. Changing biodiversity and complexity across the Middle-Upper Palaeolithic transition. In: Mellars, P., Boyle, K.V., Bar-Yosef, O., Stringer, C. (Eds.), Rethinking the Human Revolution. McDonald Institute for Archaeological Research, Cambridge, pp. 303-316.

Boyle, K.V., 2010. Rethinking the 'ecological basis of social complexity'. In: Boyle, K.V., Gamble, C., Bar-Yosef, O. (Eds.), The Upper Palaeolithic Revolution in Global Perspective. McDonald Institute for Archaeological Research, Cambridge, pp. 137-151.

Buckley, M., Collins, M., Thomas-Oates, J., Wilson, J.C., 2009. Species identification by analysis of bone collagen using matrix-assisted laser desorption/ionisation time-of-flight mass spectrometry. Rapid. Commun. Mass. Sp. 23, 3843-3854.

Buckley, M., Kansa, S., Howard, S., Campbell, S., Thomas-Oates, J., Collins, M., 2010. Distinguishing between archaeological sheep and goat bones using a single collagen peptide. J. Archaeol. Sci. 37 (1), 13-20.

Buckley, M., Kansa, S.W., 2011. Collagen fingerprinting of archaeological bone and teeth remains from Domuztepe, South Eastern Turkey. Archaeol. Anthropol. Sci. 3 (3), 271-280.

Buckley, M., Larkin, N., Collins, M., 2011. Mammoth and Mastodon collagen sequences; survival and utility. Geochim. Cosmochim. Acta 75 (7), 2007-2016.

Buckley, M., Fraser, S., Herman, J., Melton, N.D., Mulville, J., Palsdottir, A.H., 2014. Species identification of archaeological marine mammals using collagen fingerprinting. J. Archaeol. Sci. 41, 631-641.

Campana, M.G., Robinson, T., Campos, P.F., Tuross, N., 2013. Independent confirmation of a diagnostic sheep/goat peptide sequence through DNA analysis and further exploration of its taxonomic utility within the Bovidae. J. Archaeol. Sci. 40 (2), 1421-1424.

Castellano, S., Parra, G., Sanchez-Quinto, S., Racimo, F., Kuhlwilm, M., Kircher, M., Sawyer, S., Fu, Q., Heinze, A., Nickel, B., Dabney, J., Siebauer, M., White, L., Burbano, H.A., Renaud, G., Stenzel, U., Lalueza-Fox, C., de la Rasilla, M., Rosas, A., Rudan, P., Brajkovi, D., Kucan, z., Gusic, I., Shunkov, M.V., Derevianko, A.P., Viola, B., Meyer, M., Kelso, J., Andres, A.M., Pääbo, S., 2014. Patterns of coding variation in the complete exomes of three Neadertals. P. Natl. Acad. Sci. U. S. A. 111, 6666-6671.

Chritz, K.L., Dyke, G.J., Zazzo, A., Lister, A.M., Monaghan, N.T., Sigwart, J.D., 2009. Palaeobiology of an extinct Ice Age mammal: stable isotope and cementum analysis of giant deer teeth. Palaeogr. Palaeocl. Palaeoeco 282, 133-144.

Churchill, S.E., Smith, F.H., 2000. The makers of the early Aurignacian of Europe. Am. J. P. H. Anthropol. 43 (31), 61-115.

Costamagno, S., Liliane, M., Cedric, B., Vandermeersch, B., Bruno, M., 2006. Les Pradelles (Marillac-le-Franc, France): a Mousterian reindeer hunting camp? J. Anthropol. Archaeol 25, 466-484.

Costamagno, S., Beauval, C., Lange-Badre, B., Vandermeersch, B., Mann, A., Maureille, B., 2008. Homme ou carnivores? Protocole d'etude d'ensembles osseux mixtes: l'exemple du gisement Mousterien des Pradelles. P@lethnologie $1,372-400$.

Discamps, E., Jaubert, J., Bachellerie, F., 2011. Human choices and environmental constraints: deciphering the variability of large game procurement from Mousterian to Aurignacian times (MIS 5-3) in south-western France. Quat. Sci. Rev. 30, 2755-2775.

Discamps, E., 2013. Ungulate biomass fluctuations endured by Middle and Early Upper Paleolithic societies (SW France, MIS 5-3): the contributions of modern analogs and cave hyena paleodemography. Ouat. Int. 337, 64-79.

d'Errico, F., Julien, M., Liolios, D., Vanhaeren, M., Baffier, D., 2003. Many awls in our arguments: bone tool manufacture and use in the Châtelperronian and Aurignacian levels of the Grotte du Renne at Arcy-Sur-Cure. In: Zilhão, J., d'Errico, F. (Eds.), The Chronology of the Aurignacian and of the Transitional Technocomplexes: Dating, Stratigraphies, Cultural Implications. Instituto Portugues de Arqueologia, pp. 247-272.

Frouin, M., Ploquin, F., Soressi, M., Rendu, W., Macchiarelli, R., El Albani, A., Meunier, A., 2013. Clay minerals of late Pleistocene sites (Jonzac and Les Cottés, SW France): applications of X-ray diffraction analyses to local paleoclimatic and paleoenvironmental reconstructions. Quat. Int. 302, 184-198.

Gaudzinski, S., Roebroeks, W., 2000. Adults only. Reindeer hunting at the Middle Palaeolithic site SalzgitterLebenstedt, Northern Germany. J. Hum. Evol. 38, 497-521. 
Gotelli, N.J., Colwell, R.K., 2011. Estimating species richness. In: Magurran, A.E., McGill, B.J. (Eds.), Biological Diversity: Frontiers in Measurement and Assessment. Oxford University Press, Oxford, pp. 39-54.

Grayson, D., 1984. Quantitative Zooarchaeology. Academic Press, Orlando.

Grayson, D.K., Delpech, F., 2002. Specialized Early Upper Palaeolithic hunters in south-western France? J. Archaeol. Sci. 29 (12), 1439-1449.

Grayson, D.K., Delpech, F., 2008. The large mammals of Roc de Combe (Lot, France): the Châtelperronian and Aurignacian assemblages. J. Anthropol. Archaeol. 27 (3), 338-362.

Hammer, Ø., Harper, D.A.T., Ryan, P.D., 2001. PAST: paleontological statistics software package for education and data analysis. Palaeontol. Electron. 4 (1), 1-9.

Hoffecker, J., 2009. The spread of modern humans in Europe. P. Natl. Acad. Sci. U. S. A. 106 (38), 16040-16045.

Hublin, J.-J., Talamo, S., Julien, M., David, F., Connet, N., Bodu, P., Vandermeersch, B., Richards, M.P., 2012. Radiocarbon dates from the Grotte du Renne and saintCésaire support a Neandertal origin for the Châtelperronian. P. Natl. Acad. Sci. U. S. A. 109 (46), 18743-18748.

Hublin, J.-J., 2015. The modern human colonization of western Eurasia: when and where? Quat. Sci. Rev. in press http://dx.doi.org/10.1016/j.quascirev.2014.08.011.

Jacobs, Z., Li, B., Jankowski, N., Soressi, M., 2015. Testing of a single grain OSL chronology across the Middle to Upper Palaeolithic transition at Les Cottés (France). J. Archaeol. Sci. 54, 110-122.

Kintigh, K., 1984. Measuring archaeological diversity by comparison with simulated assemblages. Am. Antiq. 49, 44-54.

Kirby, D.P., Buckley, M., Promise, E., Trauger, S., Holdcraft, T.R., 2013. Identification of collagen-based materials in cultural heritage. Analyst 138 (17), 4849-4858.

Lam, Y.M., Pearson, O.M., 2005. Bone density studies and the interpretation of the faunal record. Evol. Anthropol. 14, 99-108.

Lévêque, F., 1997. Le Passage du Paléolithique moyen au Paléolithique supérieur: Données stratigraphiques de quelques gisements sous-grotte du sud-ouest. Quaternaire 8, 279-287.

Lyman, R.L., Ames, K.M., 2007. On the use of species-area curves to detect the effects of sample size. J. Archaeol. Sci. 34 (12), 1985-1990.

Lyman, R., 2008. Quantitative Paleozoology. Cambridge University Press, Cambridge.

Magurran, A.E., 2004. Measuring Biological Diversity. Wiley-Blackwell, New York.

Mellars, P., 2004. Reindeer specialization in the early Upper Palaeolithic: the evidence from south west France. J. Archaeol. Sci. 31 (5), 613-617.

Mussini, C., Crevecoeur, I., Dolores Garalda, M., Mann, A., Maureille, B., 2012. A new Neandertal femoral diaphysis from Les Pradelles (Marillica-le-Franc, Charente, France). Period. Biol. 114, 117-123.

Nielsen-Marsh, C.M., Smith, C.I., Jans, M.M.E., Nord, A., Kars, H., Collins, M.J., 2007. Bone diagensis in the European Holocene II: taphonomic and environmental considerations. J. Archaeol. Sci. 34, 1523-1531.

Niven, L., 2007. From carcass to cave: large mammal exploitation during the Aurignacian at Vogelherd, Germany. J. Hum. Evol. 53, 362-382.
Pradel, L., 1967. La grotte des Cottés, commune de Saint-Pierre-de-Maillé (Vienne) Moustérien, Périgordien, Auignacien. Datation par le radiocarbon. L'Anthropologie 71, 271-277.

Rendu, W., 2010. Hunting behavior and Neanderthal adaptability in the Late Pleistocene site of Pech-de-l'Azé I. J. Archaeol. Sci. 37 (8), 1798-1810.

Richards, M.P., Taylor, G., Steele, T., McPherron, S.P., Soressi, M., Jaubert, J. Orschiedt, J., Mallye, J.B., Rendu, W., Hublin, J.-J., 2008. Isotopic dietary analysis of a Neanderthal and associated fauna from the site of Jonzac (CharenteMaritime), France. J. Hum. Evol. 55 (1), 179-185.

Romandini, M., Nannini, N., Tagliacozzo, A., Peresani, M., 2014. The ungulate assemblage from layer A9 at Grotta di Fumane, Italy: a zooarchaeologica contribution to the reconstruction of Neanderthal ecology. Quat. Int. 337 (9), $11-27$.

Roussel, M., Soressi, M., 2013. Une nouvelle séquence du Paléolithique supérieur ancien aux marges sud-ouest du Bassin parisien : Les Cottés dans la Vienne. In: Bodu, P. (Ed.), Paléolithique supérieur ancien de l'Europe du Nord-ouest. Réflexions et synthèses à partir d'un projet collectif de recherche sur le centre et le sud du Bassin parisien, actes du colloque de Sens, Mémoire, vol. 56. Société préhistorique française, Nanterre, pp. 283-298.

Soressi, M., Roussel, M., Rendu, W. Primault, J., Rigaud, S., Texier, J.P., Richter, D. Talamo, S., Ploquin, F., Larmignat, B., Tavormina, C., Hublin, J.-J., 2010. Les Cottés (Vienne). Nouveaux travaux sur l'un des gisements de référence pour la transition Paléolithique moyen/supérieur. In: Buisson-Catil, J., Primault, J. (Eds.) Préhistoire entre Vienne et Charente: homes et societies du Paléolithique. Association des publications Chauvinoises, Chauvigny, pp. 221-234.

Soressi, M., McPherron, S.P., Lenoir, M., Dogandzic, T., Goldberg, P., Jacobs, Z. Maigrot, Y., Martisius, N.L., Miller, C.E., Rendu, W., Richards, M., Skinner, M.M. Steele, T.E., Talamo, S., Texier, J.-P., 2013. Neandertals made the first specialized bone tools in Europe. P. Natl. Acad. Sci. U. S. A. 110 (35), 14186-14190.

Soressi, M., Roussel, M., 2014. European Middle-to-Upper Palaeolithic transitiona industries: Châtelperronian. In: Smith, C. (Ed.), Encyclopedia of Global Archaeology. Springer, New York, pp. 2679-2693.

Soulier, M.C., Mallye, J.B., 2012. Hominid subsistence strategies in the South-West of France: a new look at the early Upper Palaeolithic faunal material from Roc-deCombe (Lot, France). Quat. Int. 252, 99-108.

Strohalm, M., Kavan, D., Novak, P., Volny, M., Havlicek, V., 2010. mMass 3: a crossplatform software environment for precise analysis of mass spectrometric data. Anal. Chem. 82 (11), 4648-4651.

Talamo, S., Soressi, M., Roussel, M., Richards, M., Hublin, J.-J., 2012. A radiocarbon chronology for the complete Middle to Upper Palaeolithic transitional sequence of Les Cottés (France). J. Archaeol. Sci. 39 (1), 175-183.

Todd, L.C., Rapson, D.J., 1988. Long bone fragmentation and interpration of fauna assemblages : approaches to comparative analysis. J. Archaeol. Sci. 15, 307-325.

Ulrich, W., 2006. Nestendess - a FORTRAN Program for Calculating Ecological Matrix Temperatures. Available via. www.uni.torun.pl/ ulrichw. 